Article

\title{
Towards Sustainable Waste Management through Cautious Design of Environmental Taxes: The Case of Ethiopia $^{\dagger}$
}

\author{
Merhatbeb Teklemedhn Gebregiorgs ${ }^{1,2}$ \\ 1 Tilburg Law School, Tilburg University, 5037 AB Tilburg, The Netherlands; \\ M.T.Gebregiorgs@tilburguniversity.edu \\ 2 School of Law, Mekelle University, Mekelle 231, Ethiopia \\ + This research is conducted under the affiliation of Tilburg Law School, Tilburg University, Tilburg, \\ The Netherlands; and Mekelle University School of Law, Mekelle, Ethiopia, under the supervision of \\ Professor Dr. Jonathan Verschuuren.
}

Received: 25 June 2018; Accepted: 9 August 2018; Published: 30 August 2018

check for check for
updates

\begin{abstract}
This research examines the viability of the design of environmental taxes in the achievement of sustainable waste management in the Addis Ababa Administration (AAA) of Ethiopia. It has employed an empirical qualitative method. It first shows the mutual contribution of the achievement of waste management to the progress of sustainable sanitation and water resource management. Secondly, it displays the distributive and incentive roles of environmental taxes in the achievement of sustainable waste management. Thirdly, it indicates that a cautious design of the source, base, scope and rate of environmental taxes is a critical determinant for environmental taxes' overall success in addressing the prevalent waste mismanagement in Ethiopia. Fourthly, it demonstrates that in the AAA: (1) The sources of solid waste collection, landfill, sewerage service and effluent charges are subject to the principle of legality; (2) the scope of solid waste collection, landfill, sewerage service and effluent charges is appropriate; (3) while the base of sewerage service and effluent charges is efficient, the base of solid waste and landfill charges is not at all efficient; and (4) while the rates of solid waste, landfill and sewerage service charges are slightly optimal, the rate of the effluent charge has not yet developed. Fifthly, it reveals that, having a somewhat viable design, solid waste, landfill and sewerage service charges are marginally reinforcing the aspiration of Ethiopia to achieve sustainable sanitation. Sixthly, it uncovers that because Ethiopia has not yet developed the rate of effluent charge, effluent charge is neither internalizing the cost of water resource degradation nor incentivizing sustainable water resource management. Finally, it implies that the aspiration of Ethiopia to achieve sustainable sanitation and water resource management by 2030 is contingent on the cautious design of its waste management taxes.
\end{abstract}

Keywords: SDGs; sustainable waste management; the PPP; environmental taxes

\section{Introduction}

\subsection{Background of the Research}

Sustainable waste management is one the goals of sustainable development (2030 Agenda for SD Goal 6) [1], and it is applicable both in developed and least developed countries (Agenda for SD at 2, 3, 11 and 12) [1].

The proper implementation of sustainable waste management mutually enhances the progress of sustainable sanitation and water resource management (AA AA TICFD at 5,6) [2,3]. 
Sustainable waste management is defined as 'using material resources efficiently to cut down on the amount of waste produced, and, where waste is generated, dealing with it in a way that actively contributes to sustainable development goals' [4]. Accordingly, the waste management hierarchy that shall apply as a priority order in waste prevention and management legislation and policy consists of prevention, re-use, recycling, recovery and disposal (Directive 2008/98/EC Art 4) [4].

Price-based instruments were first suggested by Pigou in 1920 in the form of taxes and subsidies to deal with detrimental and beneficial environmental externalities [5-7]. Subsequently, different sources endorsed the use of environmental taxes to achieve sustainable waste management based on the polluter-pays principle (PPP) [4,8-11].

Concurrently, De Sadeleer verified that the variation of the distributive and incentive roles of environmental taxes is according to the redistributive or incentive function of the PPP (De Sadeleer, N. at 44,46$)$ [12].

In addition, cautious design of the source, base, scope and rate of environmental taxes is a critical determinant for their overall success in the full range of waste abatement options (see details in Section 6).

\subsection{Statement of the Problem}

Ethiopia is committed to sustainable development (see details in Section 3) and introducing incentives and disincentives to discourage practices that hamper the sustainable use of natural resources and the prevention of environmental degradation and pollution (DPDEOFDREA Art 4 (33) (1) (k); DPDEOFDRE; FEPOEP Art 6 (12)) [13-15]. Moreover, each of its urban administrations has the duty to ensure environmental tax-based sustainable waste management (Gebregiorgs, M. T. (2016) at 35-39) [11].

In addition, its law must provide a broad framework for both punitive and incentive measures, and where possible its tax structure has to be designed in a way that provides environmentally friendly positive incentives and negative incentives (EPE No. 5.2 (f); NCS II No. 3.6.2 (124) (g) (k); EWRMP No. 1 (1.3) (3), 2 (2.2.5) (B) (1) and (2); EWSS at 5) [16-19].

Ethiopia has given recognition to the PPP with its redistributive, preventive and incentive functions (Gebregiorgs, M. T. (2016) at 28-32) [11]. Moreover, earlier research by this author shows that the variation of the distributive and incentive roles of environmental taxes is according to the functions of the PPP (Gebregiorgs, M. T. (2016) at 14, 15, 19 and 20; De Sadeleer, N. at 46) [11,12]. In addition, it has demonstrated the instrumental roles of solid waste, landfill, sewerage service and effluent charges in the realization of sustainable waste management (Gebregiorgs, M. T. (2016) at 35-39) [11].

Nevertheless, at the moment, Ethiopia in general and Addis Ababa in particular exposed to water resources degradation associated with effluent [18,20-25], and to the mismanagement of solid waste (AACAASWP at 1; Bjerkli, C. L. 1277-1278) [26,27], sludge, and sewage [28-30]. Furthermore, the social cost of the waste management of public authorities in the Addis Ababa Administration (AAA) is mainly covered through public subsidy [31-34].

Different sources associate unsustainable waste management with the absence of a cautious design of the source, base, scope and rate of environmental taxes (see details in Section 6). Therefore, this research will assess the viability of the design of the source, base, scope and rate of environmental taxes in the achievement of sustainable waste management in the AAA of Ethiopia.

\subsection{Research Questions}

\subsubsection{Basic Research Question}

How viable is the design of solid waste, landfill, sewerage service and effluent charges in the achievement of sustainable waste management in the AAA of Ethiopia? 


\subsubsection{Specific Research Questions}

How viable is the design of the source, base, scope and rate of:

a. Solid waste and landfill charges in the achievement of sustainable solid waste management,

b. Sewerage service charges in the achievement of sustainable sewerage service, and

c. Effluent charges in the achievement of the sustainable restoration of authorized water resources degradation in the AAA of Ethiopia?

\section{Methodology}

The research is delimited to the self-governing AAA, which is the capital city of Ethiopia and an integral part of the federal jurisdiction (FDREC Art 49 (1) (2) (3); AACGRCP Art 17 (1), 61 (2)) [35,36]. The research has employed an empirical qualitative method to assess the viability of the design of environmental taxes in the achievement of sustainable waste management in the AAA of Ethiopia. The qualitative analysis is iterative. Inferences are drawn through interpretation, and their validity is assured through primary and secondary data source triangulation. In this research, the design of the source, base, scope and rate of solid waste, landfill, sewerage service, and effluent charges is viable when the source is subject to the principle of legality, the scope is appropriate, the base is efficient, and the rate is optimal. The operationalization of the key words has been done in Section 7, through the development of a literature review-based normative framework in the context of sustainable waste management. Parallel to this, the research has used federal and AAA environmental and tax laws, official documents, key informant interviews, focus group discussions (FGD), and observation as the major sources of data on the law and practice of environmental tax-based waste management in the AAA of Ethiopia. Purposive sampling was used to select the key informants as well as the solid waste and effluent tax FGD participants, who are mainly from the Cleanliness Administration Agency; Solid Waste Re-use and Disposal Project Office; Water and Sewerage Authority; Environmental Protection Authority of the AAA; the Ministry of Water, Irrigation and Electricity; and the Ministry of Environment, Forest and Climate Change of Ethiopia. Finally, the legal and empirical data of the research is triangulated, interpreted and tested against the normative framework, and then concluding remarks and implications are presented.

\section{Organization of the Article}

The article is organized into eight further sections. After this introduction, Section 3 deals with the idea of sustainable development. Section 4 looks at sustainable waste management. Section 5 considers the polluter-pays principle. Section 6 appraises the nature, source, role, base, scope and rate of environmental tax. Section 7 develops a normative framework for the use of environmental taxes to achieve sustainable waste management. Section 8 assesses the viability of the design of the source, base, scope, and rate of environmental taxes in the achievement of sustainable waste management in the AAA of Ethiopia. Finally, Section 9 presents the conclusion and implication of the research.

\section{The Ideal of Sustainable Development}

Sustainable development [37] provides the general framework for all environmental issues (Cullet, P. at 354) [38]. The ideal (goal) of sustainable development [39,40] renders a high moral value to environmental law principles, which are meant to implement the ideal of sustainable development (Verschuuren, J. (2006) at 1; Bell, S.; McGillivray, D. at 54) [40,41]. As such, they form a necessary link between legal rules and the ideal of sustainable development (Verschuuren, J. (2006) at 2, 52, 53; Bosselmann, K. at 48) [40,42].

Sustainable development goals (SDGs) are global in nature and universally applicable. They are integrated and indivisible (2030 Agenda for SD at 2, 3, 11, 12) [1], and the achievement of a particular SDG mutually contributes to the progress of other SDGs [2,3]. Accordingly, the proper implementation of waste management mutually enhances the progress of sustainable sanitation (2030 Agenda for SD at 12) [1] and water resource management (2030 Agenda for SD at 12) [1]. 
Correspondingly, Ethiopia has national [16-19,35,43-53] and international [1,8,9,35,54-58] commitment to the idea of sustainable development. In addition, it has embraced the 2030 Agenda for Sustainable Development, Agenda 2063 of Africa, and the Addis Ababa Action Agenda, and by 2030 it is aspiring to achieve sustainable sanitation and water resource management $[1,52,53]$.

\section{Sustainable Waste Management}

Sustainable waste management [4] is one the goals of sustainable development (2030 Agenda for SD at 12) [1], and it is defined as 'using material resources efficiently to cut down on the amount of waste produced, and, where waste is generated, dealing with it in a way that actively contributes to SDGs' [4].

The various waste management options can be placed in an order known as the waste management hierarchy which reflects the relative sustainability of each [4]. Accordingly, the waste management hierarchy that shall apply as a priority order in waste prevention and management legislation and policy consists of prevention, re-use, recycling, recovery and disposal (Directive 2008/98/ECArt 4) [4].

In addition, different sources endorsed the use of environmental taxes to achieve sustainable waste management based on the PPP (Agenda 21 at 264, 2.14 (c), 4.24; Rio Declaration Principle 16; Snape, J.; de Souza, J. at 14; Gebregiorgs, M. T. (2016)) [8-11]. Correspondingly, the cautious design of the source, base, scope and rate of environmental taxes is a critical determinant for their overall success in the full range of waste abatement options (see details in Section 6).

\section{The Polluter-Pays Principle}

The word environment is derived from the French word environner, which means to encircle (Shelton, D.; Kiss, A. at 4) [59], and it is a union of abiotic and biotic factors (Gilpin, A. at 92) [60] of renewable/non-renewable natural resources (Markandya, A. et al. at 79-80) [61].

Pollution/depletion, where private benefits and costs diverge from social benefits and costs (Pigou, A. C. at 172-203; Markandya, A. et al. at 94; Alm, J.; Banzhaf, H. S. at 178) [5,61,62], is one of the classic cases of negative externality (Pigou, A. C. at 21; De Sadeleer, N. at 21; Bell, S.; McGillivray, D. at 239; Markandya, A. et al. at 5, 94; $\operatorname{OECD~(2001)~at~19)~}[5,12,41,61,63]$. Concurrently, pollutant means any substance, whether liquid, solid or gas, that is intentionally / unintentionally released (FPCP Art 2 (15); AAEPCR Art $2(14))[45,64]$ and directly/indirectly adversely affects the quality of the environment (FPCP Art 2 (11); AAEPCR Art 2 (12)) [45,64].

The PPP is one of the main outlines of sustainable development (Snape, J.; de Souza, J. at 111) [10], and it is a framework where environmental protection and environmental taxation meet (Pitrone, F. at 130) [65]. Correspondingly, it has the following functions, as discussion in Sections 5.1 and 5.2.

\subsection{Redistributive Function of the PPP}

One of the main functions of the PPP is an internalization of public authorities' social costs for pollution prevention and control (De Sadeleer, N. at 35) [12] and the safeguarding of the public budget allocation for it (Pitrone, F. at 136) [65]. Hence, polluters should reimburse the state's expenditures for pollution prevention and control (De Sadeleer, N. at 35; Shelton, D.; Kiss, A. at 4; Wolf, S.; Stanley, N. at 17; Kiss, A.; Shelton, D. at 95; Ashford, N. A.; Caldart, C. C. at 174) $[12,59,66-68]$. The redistributive function of the PPP thus envisages the internalization of the social costs borne by the public authorities for pollution prevention and control (De Sadeleer, N. at 311) [12].

From a scientific angle, degradation relates more to introducing pollutants into the ecosystem than to crossing a threshold of irreversibility. Setting an emission threshold necessarily leads to degradation that compromises the regenerative capacity of water, soil and air (De Sadeleer, N. at 37) [12]. Therefore, by stressing the curative dimension, the PPP should give rise to liability for residual damage that occurs due to authorized release and the inadequacy of established discharge thresholds (De Sadeleer, N. at 37) [12]. 


\subsection{Incentive Function of the PPP}

From the legal perspective, the PPP, with the objective of ensuring a coherent environmental policy, should be consistent with the principle of prevention. From an economic point of view, if the costs polluters must bear are greater than the benefits they anticipate from continuing their harmful behavior, they are encouraged to reduce pollution to the optimal level (De Sadeleer, N. at 36) [12].

Put at the service of prevention, the PPP means not allowing a polluter who pays to continue polluting with impunity. It therefore aims to encourage polluters to reduce their waste, and alter their waste generating behavior, rather than being content to pay taxes (Pearce, D. at 2) [69].

\section{Nature, Source, Roles, Base, Scope and Rate of Environmental Tax}

\subsection{Nature of Environmental Tax}

A levy is a tax if it is compulsory, legally enforceable, levied by a public body and intended for a public purpose, and it can be used to cover taxes, fees and charges (Snape, J.; de Souza, J. at 5; IBRD/WB at 33) [10,70].

On the basis of the European Union's Eurostat:

A tax falls into the category of environmental if the tax base is a physical unit (or a proxy for it) of something that has a proven specific negative impact on the environment, when used or released (European Commission at 9) [71].

The OECD, however, favors the terminology 'environmentally related tax' and defines it as 'any compulsory, unrequited payment to general government levied on tax-bases deemed to be of particular environmental relevance. Taxes are unrequited in the sense that benefits provided by government to tax payers are not normally in proportion to their payments (OECD (2001) at 15) [63].'

As a result, the name/stated purpose of a given fiscal instrument is not necessarily a universally applicable criterion for appraising the category of environmental tax (Joseph, S-A. at 188-190; IBRD/WB at 33) [7,70].

Correspondingly, on the basis of the definition of fiscal neutrality, a tax system should be designed so as primarily to raise revenue and not to encourage/discourage certain activities/behavior. Nevertheless, since fiscal neutrality is optimal only in the absence of externalities, changing the fiscal system in order to correct market failures is fully consistent with it. Therefore, even if environmental tax is not neutral, it is by default consistent with fiscal neutrality (Barde, J.-P. at 18) [72].

Correspondingly, in Ethiopia solid waste, landfill, sewerage service and effluent charges are indeed within the domain of the definition and nature of environmental tax set above [11].

\subsection{Source of Environmental Tax}

The modern principle of tax legality is a derivation from the great historical battles fought between legislative and executive bodies over the power of taxation (Taddese, L. at 335; Rodi, M.; Ashiabor, H. at 70$)[73,74]$.

At the minimum, the principle of tax legality means that taxation must have a legal basis, and this is recognized as a constitutional precept in most legal systems (Vanistendael, F. at 2) [75].

Since environmental tax is part of a tax system, the legal authority enacting environmental taxes must consider the principle of legality in the context of rule of law (Rodi, M.; Ashiabor, H. at 59, 71, 74 [74]. Equally, the source of environmental taxes is subject to the principle of legality, and it has to be set up by legislative acts.

\subsection{Instrumental Roles of Environmental Tax}

The bases of environmental tax vary according to the redistributive or incentive function of the PPP (De Sadeleer, N. at 46) [12]. Correspondingly, this section is allocated to appraise the distributive and incentive roles of environmental taxes in the achievement of sustainable waste management. 


\subsubsection{Distributive Roles of Environmental Tax}

Environmental fiscal reform opens the door to a new tax base, supplementing other revenue-raising efforts (IBRD/WB at 17) [70]. The underlying rationale of payment for ecosystem services is that beneficiaries of ecosystem services should compensate the stewards that maintain these services (Gomez-Baggethun, E.; Ruiz-Perez, M. at 7; UNEP at 26) [76,77]. As a result, when an environmental tax fulfills a redistributive function, the tax should be proportional to the pollution (De Sadeleer, N. at 46) [12] and the environmental risk created by commercialization (De Sadeleer, N. at 47) [12].

On the basis of the benefits received theory, the state provides various public goods and services to the society, and beneficiaries contribute in proportion to the benefits received (UNEP at 24; Bhatia, H. L. at 56) $[77,78]$. Accordingly, the distributive role assigned to environmental taxes argues in favor of the allocation of the revenue of environmental taxes for financing the environmental goal they target (De Sadeleer, N. at 47 and 48) [12].

Therefore, the distributive role of environmental tax is maintaining the ecosystem service and internalizing the social costs to the public authorities for pollution prevention and control (De Sadeleer, N. at 35, 47, 48; IBRD/WB at 20) [12,70]. Mutatis mutandis, one of the distributive roles of environmental taxes is internalizing the social cost of public authorities for waste collection, transportation, treatment and disposal.

\subsubsection{Incentive Roles of Environmental Tax}

An environmental tax is a fiscal instrument (Pitrone, F. at 127; Gaines, S. E.; Westin, R. A. at 10; Fasil, N. at 200) $[65,79,80]$ that sends environmentally friendly signals to consumers and industrialists (Wolf, S.; Stanley, N. at 472) [66]. These taxes are the most emblematic instruments of the simultaneous intervention of the polluter-pays and prevention principles (De Sadeleer, N. at 47) [12].

Their incentive role encompasses a wide range of environmental taxes and encourages a more equal mix between cleaner production processes (De Sadeleer, N. at 47; Bell, S.; McGillivray, D. at 239; OECD (2001) at 20; IBRD/WB at 36; Kosonen, K. at 1) [12,41,63,70,81], innovation (Alm, J.; Banzhaf, H. S. at 179; Kolstad, C. D. at 151; Kosonen, K. at 1; Stewart, R. B. at 174) [62,82-84], end-of-pipe abatement measures (UNEP at 23; Stewart, R. B. at 175-176) [77,84], adoption of products that cause less pollution, development of less-polluting products and reduction of consumption (OECD (2011) at 4) [85]. Mutatis mutandis, one of the incentive roles of environmental taxes is encouraging the full range of waste abatement options.

\subsection{Base of Environmental Tax}

Environmental tax bases should be targeted to the pollutant (FPCP Art 2 (11); AAEPCR Art 2 (12)) $[45,64]$ or the polluting behavior (OECD (2011) at 4) [84]. Using the tax to increase the market cost of the polluting activity helps to incentivize the full range of potential abatement options (OECD (2011) at 4) [85].

Alternatively, when taxing the pollutant directly is not administratively feasible, a close proxy for the polluting activity can provide a good tax base (OECD (2011) at 4) [85]. Nevertheless, it is important to note that levying the tax (OECD (2011) at 4) [85]:

a. At higher levels of the supply chain would not treat the full range of solutions equally;

b. On intermediate goods constitutes an implicit tax that may not be transparent and can contribute to misspecification of tax rates.

In parallel, tax reform should take care of statutory incidence, which refers to who legally pays the tax, as well as economic incidence, which refers to who really bears the burden of the tax (Kosonen, K. at 2) [82].

Mutatis mutandis, in waste management, the base of an environmental tax is efficient when it is targeted to the waste or waste-generating behavior, which helps to incentivize the full range of waste abatement options and can contribute to specification of an optimal tax rate. 


\subsection{Scope of Environmental Tax in a Federal System}

A well-drafted tax law has to precisely spell out all the matters that are within its scope [74]. The scope of environmental tax is appropriate when it is as broad as the scope of the environmental damage being addressed (OECD (2011) at 5) [85].

The scope of environmental tax has implications for the level of political jurisdiction that imposes the tax (OECD (2011) at 5) [85]. Accordingly, if a fully functioning federal system (Vanistendael, F. at 49; Fasil, N. at 38) $[75,80]$ offers some choice as to the level of government that should act to reduce environmental pollution, the first and most important principle is the geographic scope of the externality. If the effects of waste fall within the same jurisdiction as the source, then local governments are probably best situated to address the externality. However, if the waste has significant transboundary effects, then the national government is better positioned to address it (Alm, J.; Banzhaf, H. S. at 196, 197) [62]. The second principle is that the instrument should be consistent with the fiscal needs of the level of government (Alm, J.; Banzhaf, H. S. at 187, 197) [62].

Mutatis mutandis, the scope of environmental tax in a federal system is appropriate when it is as broad as the scope of the waste being addressed, and it is consistent with the fiscal needs of the federal and regional waste management organs.

\subsection{Rate of Environmental Tax}

According to Pigou, the optimal tax rate is where the marginal benefit of abatement equals the marginal cost of abatement [5]. Increasing and lowering of tax rates is one of the instruments for manipulating the fiscal policy of a government (Fasil, N. at 200) [80].

Since environmental taxes are part of the environmental policy instrument tool box, their tax rates should be in line with environmental policy objectives (Rodi, M.; Ashiabor, H. at 70) [74]. Equally, to reach an environmental objective, it is important that the rate of an environmental tax is set at a correct level. A levy that is too low will not be able to fully correct a distortion in the market, while a levy that is too high replaces one distortion with another (Commission of the European Communities at 1) [86].

Mutatis mutandis, the rate of environmental tax is optimal when it is commensurate with the cost of waste management, and it creates an incentive for the realization of sustainable waste management (Directive 2008/98/EC Preamble No. 25, Art 14 (1); De Sadeleer, N. at 46 and 47; OECD (2011) at 1) [4,12,85].

\section{Interim Conclusion: Normative Framework for the Use of Environmental Taxes to Achieve Sustainable Waste Management}

Sustainable waste management is one the goals of sustainable development (2030 Agenda for SD at 12) [1], and it is defined as 'using material resources efficiently to cut down on the amount of waste produced, and, where waste is generated, dealing with it in a way that actively contributes to SDGs' [4]. Accordingly, the waste management hierarchy that shall apply as a priority order in waste prevention and management legislation and policy consists of prevention, re-use, recycling, recovery and disposal (Directive 2008/98/EC Art 4) [4].

Different sources have endorsed the use of environmental taxes to achieve sustainable waste management based on the PPP (Agenda 21 at 264, 2.14 (c) and 4.24; Rio Declaration Principle 16; Snape, J.; de Souza, J. at 14; Gebregiorgs, M. T. (2016)) [8-11]. Concomitantly, cautious design of the source, base, scope and rate of environmental taxes is a critical determinant for their overall success in the full range of waste abatement options (see details in Section 6). Correspondingly, the following are the interim conclusions of this research:

1. The distributive and incentive roles of environmental taxes vary according to the redistributive or incentive function of the PPP (for details, see Sections 5 and 6.3),

2. SDGs are integrated and indivisible, and the achievement of one SDG mutually contributes to the progress of others (for details, see Sections 3 and 4), 
3. The proper implementation of waste prevention, re-use, recycling, recovery and disposal mutually contributes to the progress of sustainable sanitation and water resource management (for details, see Section 4),

4. To avoid taxation without representation, the source of environmental taxes must be subject to the principle of legality in the context of rule of law (for details, see Section 6.2),

5. The scope of environmental tax in a federal system is appropriate when it is as broad as the scope of the waste being addressed and it is consistent with the fiscal needs of the federal and regional waste management organs (for details, see Section 6.5),

6. The base of environmental tax is efficient when it is targeted to the waste or waste generating behavior and it helps to incentivize the full range of waste abatement options and can contribute to specification of an optimal tax rate (for details, see Section 6.4), and

7. The rate of environmental tax is optimal when it is commensurate with the cost of waste management and it creates an incentive for the realization of sustainable waste management (for details, see Section 6.6).

Ethiopia is committed to a federal system, sustainable waste management, the PPP and the distributive and incentive roles of environmental taxes in the achievement of sustainable waste management. Correspondingly, in this research, the design of solid waste, landfill, sewerage service and effluent charges is considered to be viable in the achievement of sustainable waste management when the source is subject to the principle of legality, the scope is appropriate, the base is efficient, and the rate is optimal.

\section{The Viability of the Design of Environmental Taxes in the Achievement of Sustainable Waste Management in the AAA of Ethiopia}

\subsection{Constitutional and International Law Bases of Environmental Taxes in Ethiopia}

\subsubsection{Constitutional Law}

Environmental tax law is subject to the constitutional precondition of a given nation and in some cases to the relevant international laws (Rodi, M.; Ashiabor, H. at 59) [74].

The federal constitution of Ethiopia is the supreme law of the land (FDREC Art 9 (1)) [35], and the fundamental authority to tax is derived from it (Taddese, L. at 330) [73]. Even though the constitution does not explicitly require taxation to have a firm basis in law, it can be inferred from its provisions that it grants the federal and regional legislative organs the power to impose taxes on their respective sources (FDREC Art 51, 52, 55; Taddese, L. at 337) [35,73].

On the basis of its directives on taxation (FDREC Art 100) [35]:

1. In exercising their taxing powers, States and the Federal Government shall ensure that any tax is related to the source of revenue taxed and that it is determined following proper considerations.

2. They shall ensure that the tax does not adversely affect their relationship and that the rate and amount of taxes shall be commensurate with services the taxes help deliver.

In addition, the scope of the constitution regarding tax is broadly designed in a way that it encompasses both federal and states' benefit and non-benefit taxes, which are the bases of a range of environmental taxes (FDREC Art 96, 97 and 98; AACGRCP Art 52, 53, 61) $[35,36]$.

\subsubsection{International Law}

'The authority of the state to legislate in tax matters may be limited by international treaties and agreements' (Vanistendael, F. at 16) [75]. Equally, the authority to legislate environmental taxes must safeguard the framework of public international law (Rodi, M.; Ashiabor, H. at 79) [74], and one of the prerequisites to its application is conformity with international law (Barde, J.-P. at 23, 28) [72]. 
In Ethiopia, all international agreements established by the federal government shall protect and ensure Ethiopia's right to sustainable development (FDREC (n19) Art 43 (3)) [35]. Concurrently, all international agreements ratified by the federal government are an integral part of the law of the land, and they are part of the constitutional interpretation clauses (FDREC Art 9 (4), 13 (2), 43 (3), 51 (8), 55 (12)) [35].

Ethiopia is committed to developing a national environmental liability and compensation regime (Rio Declaration Principle 7, 11, 13) [9]. In addition, since Ethiopia has an international commitment to the use of environmental taxes to achieve sustainable waste management, it can use environmental tax to revitalize its global partnership for sustainable development (2030 Agenda for SD Goal 6; Agenda 21 at 2.14 (c), 4.24; Rio Declaration Principle 16) [1,8,9].

\subsubsection{International Trade}

The federal government of Ethiopia has the duty to enact specific laws that regulate foreign trade and forge and promote mutual interest-based economic union and relations (FDREC Art 51 (4) (8) (12), $55(2)(b), 86)$ [35].

To that effect, it has applied to the World Trade Organization (WTO), and its application was received on 13 January 2003 [87]. In line with the Most-Favoured-Nation Treatment Principle [88] and the Chapeau of Article XX [88], General Agreement on Tariffs and Trade (GATT) recognizes the adoption/enforcement by any contracting party of measures necessary to protect human, animal/plant life/health and to conserve exhaustible natural resources (GATT Art XX (b) and (g)) [88].

Thus, the use of environmental taxes to achieve sustainable waste management is congruent with Ethiopia's foreign trade policy and its endeavor to accede to the WTO.

\subsection{Source of Solid Waste Management, Sewerage Service and Effluent Charges}

To avoid taxation without representation, the legal authority enacting environmental taxes must take a variety of material restrictions into account, including constitutional principles such as the principle of legality in the context of rule of law (Rodi, M.; Ashiabor, H. at 59) [74].

Accordingly, Ethiopia is strongly committed to building a political community based on the rule of law, and its states have the duty to do their best to advance the rule of law (FDREC Preamble and Art 52 (2) (a)) [35]. Moreover, in Ethiopia in general and Addis Ababa in particular, it is established that no public money shall be collected except when authorized by law (AACGRCP Art 52, 58 (1); FGEFAP Art 10 (1); AAFAP Art 10 (1)) [36,89,90].

In addition, since Ethiopia is part of the civil law legal system (Tesfaye, A. at 32, 58) [91], its substantive and procedural laws pertaining to taxation flow from tax proclamations, regulations and directives (Taddese, L. at 356) [73]. Accordingly, its federal and AAA laws have to be published in the Federal Negarit Gazeta (FNGEP Art 2 (1) and 2 (2); HPRERPMCCR Art 58) [92,93] and Addis Negarit Gazeta, respectively; and all persons shall take judicial notice of them (AACGRCP Preamble, Art 61 (7); Fasil, N. at 86; FNGEP Art 2 (3); AAFAR Art 24) [36,82,92,94].

Furthermore, in Ethiopia interpretation of a law by the Federal Supreme Court rendered by the cassation division with not less than five judges shall be binding on federal as well as regional courts at all levels (FCPRAP Art 2 (1); FCP Art 10) [95,96]. Concomitantly, a recent ruling by the Cassation Division of the Federal Supreme Court has indicated that to have a legally binding effect, directives do not have to be published in the Negarit Gazeta, or to be displayed in a specified language [97]. Additionally, in service delivery-based charges, the provisions of a contract lawfully formed between two or more persons shall be binding on the parties as though they were law (CCEEP Art 1675 and 1731 (1)) [98].

Subsequently, in Ethiopia, when environmental tax is incorporated in any of the foregoing sources of law, it is authorized by law and all persons shall take judicial notice of it.

Accordingly, the solid waste management [99,100], sewerage services [101-103] and federal effluent $[104,105]$ charges in the AAA are set up by legislative acts, and everyone is bound to take 
judicial notice of them. Thus, their sources are subject to the principle of legality in the context of rule of law and, in turn, there is no ground for environmental taxation without representation.

\subsection{Scope of Solid Waste Management, Sewerage Service and Effluent Charges}

The scope of environmental tax in a federal system is appropriate when it is as broad as the scope of the waste being addressed and it is consistent with the fiscal needs of the federal and regional waste management organs (see details in Section 6.5). In parallel, this section will assess how appropriate the scope of solid waste management, sewerage service and effluent charges is in the AAA of the Federal Democratic Republic of Ethiopia.

\subsubsection{Environmental and Fiscal Federalism in Ethiopia}

The term 'federal' comes from the Latin word foedus, meaning 'treaty.' A federation is a dual polity where the distribution of power between the federal and state governments is strictly constitutional (Fasil, N. at 36) [80], and fiscal federalism is a process of redistribution of fiscal decision-making power across multi-leveled governments in an effort to achieve sustainable development (Abu, G. at 1; De Mello, L. R., J. R. at 365) [106,107].

'The Federal Democratic Republic of Ethiopia comprises the federal government and the state members' (FDREC Art 1, 50 (1)) [35]. The federal government of Ethiopia has the mandate to enact specific laws on the utilization and conservation of land and other natural resources, as well as of rivers and lakes crossing the boundaries of the national territorial jurisdiction or linking two/more states (FDREC Art 55 (2) (a)) [35]. Moreover, it shall determine and administer the utilization of the waters/rivers and lakes linking two/more states or crossing its territorial boundaries (FDREC Art 51 (11)) [35]. Simultaneously, all residual powers not expressly given to the federal or concurrent jurisdictions are reserved to the states (FDREC Art 52 (1)) [35]. Additionally, states have the power 'to administer land and other natural resources in accordance with federal laws (Gebregiorgs, M. T. (2016) at 26; FEPOEP Art 15 (2); FDREC Art 52 (2) (d); FPCP Art 6 (4); Alm, J.; Banzhaf, H. S. at 194; Oates, W. E. at 1) $[11,15,45,62,107,108] . '$

Furthermore, in Ethiopia there are federal, state, concurrent and undesignated powers of taxation (FDREC Art 96-99) [35]. Concurrently, the federal government and the states shall share revenue, taking the federal arrangement into account, and they shall respectively bear all financial expenditures necessary to carry out all responsibilities and functions assigned to them by law (FDREC Art 94 (1), 95) [35]. Therefore, the fiscal federalism of Ethiopia has room for the introduction of federal and state revenue-providing instruments that are consistent with their fiscal needs.

\subsubsection{Scope of Solid Waste Management and Sewerage Service Charges}

In a federal system, if the effects of waste fall within the same jurisdiction as the source, then local governments are probably best situated to address the externality through the institution of an environmental tax-based waste management system (Alm, J.; Banzhaf, H. S. at 196-197) [62].

In Ethiopia all urban administrations are bound to ensure sustainable municipal waste collection, transportation, recycling, treatment and safe disposal through the institution of an environmental tax-based waste management system [11].

Accordingly, the Addis Ababa Cleanliness Administration Agency (AACAA) [99,100,109], the Addis Ababa Solid Waste Re-use and Disposal Project Office (AASWRDPO) [99,109], and the Addis Ababa Water and Sewerage Authority (AAWSA) [99,101-103,109] are respectively bound to ensure environmental tax-based sustainable solid waste collection, landfill, and sewerage services in the AAA (AAWMCDR Art 25) [99].

The scope of the solid waste, landfill and sewerage service charges of the AAA is as broad as the scope of the municipal waste damage being addressed and the fiscal needs of the AACAA, AASWRDPO and AAWSA respectively. Therefore, it is safe to conclude that the scope of the solid waste management and sewerage service charges of the AAA is appropriate. 


\subsubsection{Scope of Effluent Charge}

In a federal system, if the waste has significant transboundary effects, then the national government is better positioned to address the externality through the institution of an environmental tax-based waste management system (Alm, J.; Banzhaf, H. S. at 196-197) [62].

Accordingly, in Ethiopia, the federal government has the mandate to administer rivers linking two or more states or crossing the territorial jurisdiction of Ethiopia (FDREC Art 51 (11)) [35]. Concurrently, the Ministry of Water, Irrigation and Electricity of Ethiopia (MWIEE) is bound to address the externality through the practical implementation of an effluent charge (EFWRMP Art 20 (1) (c), 22) [104].

The scope of the federal effluent charge of Ethiopia is as broad as the scope of the degradation of the water resources being addressed and the fiscal needs of the MWIEE. Thus, it is safe to conclude that the scope of the federal effluent charge of Ethiopia is appropriate.

\subsection{Base of Solid Waste Management, Sewerage Service and Effluent Charges}

The base of an environmental tax is efficient when it is targeted to the waste or waste generating behavior, which helps to incentivize the full range of waste abatement options and can contribute to specifying an optimal tax rate (see details in Section 6.4). Concurrently, this section will appraise the efficiency of the base of solid waste management, sewerage service and effluent charges in the AAA.

\subsubsection{Base of Solid Waste Management Charges}

In the AAA, the Addis Ababa Cleanliness Administration Agency (AACAA) and the Addis Ababa Solid Waste Re-use and Disposal Project Office (AASWRDPO) are bound to ensure environmental tax-based sustainable solid waste management (RDCSSTAACG Art 5 (1)) [100].

On the basis of the Solid Waste Management Proclamation of Ethiopia, 'solid waste is anything that is neither liquid nor gas and is discarded as unwanted (AAWMCDR Art 2 (3); RDCSSTAACG Art 2 (9); SWMP Art 2 (6)) $[99,100,110]$.' Correspondingly, the base of solid waste and landfill charges is efficient when it is targeted to the solid waste (see details in Section 6.4).

In practice, water consumption is taken as the base of solid waste and landfill charges (RDCSSTAACG Art 5 (1)) [100]. Since targeting water consumption as the base of the charges does not increase the market cost of the polluting activity, it does not incentivize a full range of solid waste abatement options (OECD (2011) at 4) [85]. Additionally, it does not help to specify an optimal rate for solid waste and landfill charges that is commensurate with the AACAA and AASWRDPO solid waste collection and landfill services respectively.

As a corollary, taking water consumption as the base of solid waste and landfill charges of the AAA is not at all efficient.

\subsubsection{Base of Sewerage Service Charges}

\section{Base of Sludge Dislodging Service Charge}

At the moment, Addis Ababa Water and Sewerage Authority (AAWSA) is bound to provide a sludge dislodging service through the implementation of a sludge dislodging charge (AAWSSDSRRR Art 6 (1) and (2), Schedule III, No. 1 and 2) [102].

On the basis of the AAWSA Re-establishment Proclamation, 'sludge is the content of any waste water settled in waste water facilities (AAWSARP Art 2 (22)) [101],' and it is targeted as the base of the sludge dislodging charge (AAWSSDSRRR Art 6 (1) and (2), Schedule III, No. 1 and 2) [102].

Targeting the volume of the sludge, the pollutant, as the base of the charge increases the market cost of the polluting activity, which helps to incentivize the full range of sludge abatement options. In addition, it helps to specify an optimal sludge dislodging charge rate that is commensurate with AAWSA and with private sludge dislodging services.

Thus, it is safe to conclude that taking sludge as the base of the sludge dislodging charge of the AAA is efficient. 


\section{Base of Sewer Service Charge}

At the moment in the AAA, there is 10\% sewer service coverage [111-116] and the Addis Ababa Water and Sewerage Authority (AAWSA) is bound to deliver sewer service through the implementation of a sewer service charge (AAWSSDSRRR Schedule I) [101].

In sewerage management, the base of the sewer service charge is efficient when it is targeted to sewage (AAWSARP Art 2 (23)) [101], the pollutant, or to its close proxy. In practice, water consumption in cubic meters, which is a close proxy of sewage, is targeted as the base of the sewer service charge of the AAA (AAWSSDSRRR Schedule I) [102].

Targeting water consumption in cubic meters as the base of the charge increases the market cost of the polluting activity, which by and large helps to incentivize a full range of sewage abatement options. In addition, it helps to specify an optimal sewer service charge rate that is commensurate with AAWSA sewer service.

Therefore, it is safe to conclude that taking water consumption in cubic meters as the base of the sewer service charge of the AAA is by and large efficient.

\subsubsection{Base of Effluent Charge}

In Ethiopia, the Ministry of Water, Irrigation and Electricity (MWIEE) may issue permits for the release of treated waste into rivers linking two or more states or crossing the territorial jurisdiction of Ethiopia and may collect effluent charges from permit holders (EFWRMP Art 11 (1) (d), 13 (2), 20 (1) (c), 22; EWRMR Art 5, 11, 12, 13, 14, 32) [104,105].

On the basis of the Ethiopian Water Resources Management Proclamation, 'waste means any harmful matter introduced, released or discharged into any water body in any solid, liquid or gaseous form (EFWRMP Art 2 (10)) [104],' and it is targeted as the base of the effluent charge (EWRMR Art 12 (1) (b)) [105].

Targeting the type and volume of waste as the base of the effluent charge helps to incentivize the full range of effluent abatement options (OECD (2011) at 4) [85]. In addition, it helps to specify an optimal effluent charge rate that is commensurate with MWIEE restoration of authorized degradation of rivers linking two or more states or crossing the territorial jurisdiction of Ethiopia.

Therefore, it is safe to conclude that taking the type and volume of treated waste as the base of the federal effluent charge of Ethiopia is efficient.

\subsection{Rate of Solid Waste Management, Sewerage Service and Effluent Charges}

An unregulated market has room for unabated externalities (Pigou, A. C. at 134; Alm, J.; Banzhaf, H. S. at 179; Ashford, N. A.; Caldart, C. C. at 132; Stewart, R. B. at 172) $[5,62,68,84]$, and grants an implicit subsidy to polluters (Murty, M. N. at 130; Snape, J.; de Souza, J. at 119) [6,10]. Therefore, when a market fails (Markandya, A. et al. at 129; Bhatia, H. L. at 5) [61,78] to appreciate the opportunity costs of environmental use, it causes overuse of the environment and overproduction of ecologically harmful products (Siebert, H. at 17,18) [117].

Meanwhile, environmental tax provides an ideal means of injecting appropriate price signals and creating markets for unpriced resources and environmental services (Pigou, A. C. at 172; Murty, M. N. at 128; Bell, S.; McGillivray, D. at 239; Barde, J-P. at 10; UNEP at 29) $[5,6,41,72,77]$, and its revenue achieves its distributive role when it is used for financing the environmental goal it targets (De Sadeleer, N. at 47,48$)$ [12].

In addition, the rate of environmental tax is optimal when it is commensurate with the cost of waste management, and it creates an incentive for the realization of sustainable waste management (UNEP at 23; Stewart, R. B. at 175-176) [77,84]. Correspondingly, this section will assess whether the rates of the solid waste management, sewerage service and effluent charges in the AAA are optimal or not. 


\subsubsection{Rate of Solid Waste Management Charges}

On the basis of the Solid Waste Management Proclamation of Ethiopia, 'solid waste management means the collection, transportation, storage, recycling or disposal of solid waste, or the subsequent use of a disposal site that is no longer operational (SWMP Art 2 (7)) [110].' Concurrently, this section is allocated to appraise how optimal the rates of solid waste and landfill charges are in the realization of sustainable solid waste management.

\section{Rate of Solid Waste Collection Service Charge}

In the AAA, the Addis Ababa Cleanliness Administration Agency is bound to internalize the social cost of its solid waste collection service and to incentivize sustainable solid waste management through the implementation of a solid waste charge (Gebregiorgs, M. T. (2016) at 35-37; FPCP Art 5 (1); AAWMCDR Art 25 (1) and (2); RDCSSTAACG preamble, Art 3, 5, 6; AAEMSORP Art 53 (6), 55) $[11,45,98,99,109,118-123]$.

Accordingly, on the basis of Regulation 25/2009, the revenue of the solid waste charge shall be used for implementing the following activities (RDCSSTAACG Art 6) [100]:

1. For payment of the sanitary service activity in the city that is ordered by the agency according to its contractual service;

2. To purchase sanitary vehicles, machinery and other items that are necessary for the sanitary service of the city;

3. To fulfill different suitable modern technologies that help to improve the sanitation of the city;

4. To reward and encourage the workers and institutions that make great contributions to the sanitary service of the city; and

5. To undertake research, counseling activities and other related works that could help the sanitation service of the city.

In practice, AACAA is collecting a solid waste charge from households and organizations with their monthly water bill, which is computed on the basis of the following schedule (RDCSSTAACG Art 5 (1), Annex 1; AACAA AR 2015 at 29; AACAA AR 2016 at 14; AACAA AR 2017 at 4, 20) [100,124-126], as show in Table 1.

Table 1. Sanitary Service Tariff that is collected with the Water Bill.

\begin{tabular}{|c|c|c|c|c|}
\hline No. & Name of the Customer & $\begin{array}{l}\text { The Tariff Rate of } \\
\text { Water Sewerage }\left(\mathrm{m}^{3}\right)\end{array}$ & $\begin{array}{l}\text { The Previous Tariff Rate } \\
\text { of Sanitary Service (\%) }\end{array}$ & $\begin{array}{l}\text { The Revised Tariff Rate } \\
\text { of Sanitary Service (\%) }\end{array}$ \\
\hline 1 & $\begin{array}{l}\text { The common public } \\
\text { water service }\end{array}$ & 1.75 & 0 & 5 \\
\hline \multirow[t]{4}{*}{2} & [Household customers] & & & \\
\hline & $>$ From $0-7 \mathrm{~m}^{3}$ & 1.75 & 5 & 20 \\
\hline & $>$ From $7-20 \mathrm{~m}^{3}$ & 3.15 & 5 & 20 \\
\hline & $>$ From $20 \mathrm{~m}^{3}$ & 3.80 & 5 & 20 \\
\hline 3 & $\begin{array}{l}\text { Customers other than } \\
\text { household customers }\end{array}$ & 3.80 & 0 & 42.5 \\
\hline
\end{tabular}

However, since the rate of the solid waste charge is so nominal [119-123], and there is only a partly effective solid waste charge collection system (Gebregiorgs, M. T. (2018) at 346-352) [119-123,127], AACAA is slightly translating the distributive role of the solid waste charge into action (AACAA AR 2015; AACAA AR 2016 at 14; AACAA AR 2017 at 4, 20 and 36) [119-126].

As a result, the lion's share of the social cost of its solid waste collection service (AACAA AR 2015 at 4 , 25; AACAA AR 2016 at 3, 11; AACAA AR 2017 at 3, 19) [124-126] is covered by the subsidy it is allocated from AAA (AACG 2006 E.C. FY BP at Table 2 No. 523; AACG 2007 E.C. FY BP at Table 2 No. 523; AACG 2008 E.C. FY BP at Table 2 No. 523; AACG 2009 E.C. FY BP at Table 2 No. 523) [31-34,119-123]. 


\section{Rate of Landfill Charge}

The landfill charge is a levy on the landfilling of waste, and its goals are to internalize the environmental costs of landfill; to give better price signals for alternatives to landfill; and to assist in meeting waste targets in the most efficient way (Snape, J.; de Souza, J. at 4, 115 and 214) [10].

In the AAA, the Addis Ababa Solid Waste Re-use and Disposal Project Office (AASWRDPO) is bound to internalize the social cost of its landfill service and to incentivize sustainable solid waste management through the practical implementation of a landfill charge (Gebregiorgs, M. T. (2016) at 35-37; FPCP Art 5 (1); AAWMCDR Art 25 (1) and (2); RDCSSTAACG Art 5 (3) (b); AAEMSORP Art 53 (6), 58) $[11,45,99,100,109,123,128,129]$.

In practice, AASWRDPO is collecting 4 ETB (USD 0.15) $/ 1 \mathrm{~m}^{3}$ landfill charge in tandem with the solid waste charge of the AACAA (AASWRDPO AR 2015; AASWRDPO AR 2016 at 16; AASWRDPO AR 2017) at 4, 17) [130-132].

Nevertheless, since the rate of the landfill charge is so nominal $[123,128,129]$ and there is only a partly effective landfill charge collection system (Gebregiorgs, M. T. (2018) at 353-355) [119-123,127], AASWRDPO is slightly translating the distributive role of the landfill charge into action $[123,128,129]$. Consequently, the lion's share of the social cost of its landfill service (AASWRDPO AR 2015, AASWRDPO AR 2016 at 9; AASWRDPO AR 2017 at 4, 15) [130-132] is covered by the subsidy it is allocated from AAA (AACG 2006 E.C. FY BP Table 2 No. 524; AACG 2007 E.C. FY BP Table 2 No. 524; AACG 2008 E.C. FY BP at Table 2 No. 524; AACG 2009 E.C. FY BP at Table 2 No. 524) [31-34,123,128,129].

Simultaneously, since the rates of the solid waste and landfill charges are nominal, they are not creating an incentive for the residents of the AAA to sustainably manage their solid waste. (Bjerkli, C. L. at 1277,1278$)[27,119,120,123,128,129,133]$.

Therefore, it is safe to conclude that at the moment, the solid waste and landfill charges of the AAA are slightly optimal and they are marginally reinforcing the aspiration of Ethiopia to achieve sanitation for all by 2030 .

\subsubsection{Rate of Sewerage Service Charges}

On the basis of the Addis Ababa Water and Sewerage Authority (AAWSA) Re-establishment Proclamation, 'sewerage service shall mean the collection, treatment and disposal of waste water/sewage' (AAWSARP Art 2 (21)) [101].

In the AAA, the AAWSA is bound to internalize the social cost of its sewerage service, and to incentivize sustainable sewerage management through the practical implementation of sewerage service charges: Sludge dislodging and sewer service charges (Gebregiorgs, M. T. (2016) at 38, 39; FPCP Art 5 (1); AAWMCDR Art 25 (1) and (2); AAWSARP Art 5 (2), 7 (1); 14 (2) and 25; AAWSSDSRRR Preamble, Art 6, 39 and Schedule I and III; AAEMSORP Art 53 (6) and 59) [11,45,98,101,102,109,111,114,134,135]. Concurrently, this section is allocated to appraise how optimal the rates of sludge dislodging, and sewer service charges are in the realization of sustainable sewerage service.

\section{Rate of Sludge Dislodging Charge}

The AAWSA has a special mandate that allows it to collect a sludge dislodging charge for its vacuum trucks-based sludge dislodging service (AAWSARP Art 16 (2) (a); AAWSSDSRRR Art 39 (1)) [101,102].

Accordingly, it is collecting a 176 ETB (USD 6.46) sludge dislodging charge per trip from its household customers [111,134-138].

Nevertheless, since the rate of the sludge dislodging charge is so nominal [111,114,134-138], AAWSA is slightly translating the distributive role of its sludge dislodging charge [111,114,134-138].

\section{Rate of Sewer Service Charge}

At the moment, in the AAA there is $10 \%$ sewer service coverage and the Addis Ababa Water and Sewerage Authority (AAWSA) is bound to deliver sewer service through the implementation 
of a sewer service charge (AAWSSDSRRR Schedule I) [102]. Accordingly, in 2010, on the basis of Regulation No. 31/2002, the AAWSA was collecting sewer service charges on the basis of the rates indicated in the following tables (AAWSSDSRRR Art 5, Schedule I) [102].

Table 2. Five Years Tariff for Sewerage Disposal Service of AAWSA.

\begin{tabular}{|c|c|c|c|c|c|c|}
\hline \multirow[t]{2}{*}{ Block } & & $\begin{array}{l}\text { First Year Tariff } \\
8 \text { July } 2002 \text { to } \\
7 \text { July } 2003\end{array}$ & $\begin{array}{l}\text { Second Year Tariff } \\
8 \text { July } 2003 \text { to } \\
7 \text { July } 2004\end{array}$ & $\begin{array}{l}\text { Third Year Tariff } \\
8 \text { July } 2004 \text { to } \\
7 \text { July } 2005\end{array}$ & $\begin{array}{l}\text { Fourth Year Tariff } \\
8 \text { July } 2005 \text { to } \\
7 \text { July } 2006\end{array}$ & $\begin{array}{l}\text { Fifth Year Tariff } \\
\text { 8 July } 2006 \text { to } \\
\text { 7 July } 2007\end{array}$ \\
\hline & & Tariff $/ \mathrm{m}^{3}$ (in Birr) & Tariff/m $/ \mathrm{m}^{3}$ (in Birr) & Tariff $/ \mathrm{m}^{3}$ (in Birr) & Tariff/m $\mathbf{m}^{3}$ (in Birr) & Tariff $/ \mathrm{m}^{3}$ (in Birr) \\
\hline \multicolumn{2}{|l|}{ Public Fountain } & $\begin{array}{l}\text { Sewerage } \\
-\end{array}$ & $\begin{array}{l}\text { Sewerage } \\
-\end{array}$ & $\begin{array}{l}\text { Sewerage } \\
\text { - }\end{array}$ & $\begin{array}{l}\text { Sewerage } \\
\text { - }\end{array}$ & $\begin{array}{l}\text { Sewerage } \\
-\end{array}$ \\
\hline \multirow{3}{*}{$\begin{array}{l}\text { Domestic Customers (Monthly Water } \\
\text { Consumption in Cubic Meters) }\end{array}$} & $0-7$ & - & - & & - & - \\
\hline & Above 7 up to 20 & 0.35 & 0.40 & 0.45 & 0.50 & 0.55 \\
\hline & Above 20 & 0.35 & 0.40 & 0.45 & 0.50 & 0.55 \\
\hline Non-domestic Consumers & & 0.35 & 0.40 & 0.45 & 0.50 & 0.55 \\
\hline
\end{tabular}

Later on, in 2011, with the objective to enhance the internalization of the cost of its water supply and sewerage disposal service, AAA amended Schedule I of Regulation No. 31/2002 without explicitly indicating the rate of the sewer service charge (AAWSSDSRA Preamble) [103].

For that reason, at the moment, it is hardly possible to clearly see whether the rate of the sewer service charge is optimal or not and to trace the specific destination of the revenue it generates.

As a logical extension of the foregoing points, the lion's share of the social cost of the sewer (AAWSA WWTRSP 2015 AR at 1; AAWSA WWTRSP 2016 AR at 101; AAWSA WWTRSP 2017 AR at 72) [28-30], sludge dislodging (AAWSA WWTRSP 2015 AR at 1, 2; AAWSA WWTRSP 2016 AR at 102; AAWSA WWTRSP 2017 AR at 72) [28-30], and waste water treatment and disposal (AAWSA WWTRSP 2015 AR at 1, 2; AAWSA WWTRSP 2016 AR at 101, 102; AAWSA WWTRSP 2017 AR at 72, 73) [28-30] services of the AAWSA is covered by the subsidy it is allocated from AAA (AACG 2006 E.C. FY BP Table 2 No. 221; AACG 2007 E.C. FY BP Table 2 No. 221; AACG 2008 E.C. FY BP at Table 2 No. 221; AACG 2009 E.C. FY BP (n18) at Table 2 No. 221) [31-34,111,114,134-138].

In addition, because the rate of the sewerage service charges is nominal, it is not creating an incentive for the residents of the AAA to sustainably manage their sludge and sewage [111,114,134-140].

Therefore, it is safe to conclude that, at the moment, the sewerage service charge of the AAA is slightly optimal and is marginally reinforcing the aspiration of Ethiopia to achieve sanitation for all by 2030.

\subsubsection{Rate of Effluent Charge}

In Ethiopia, all water resources are the common property of the Ethiopian people and the state (EWRMP at 1.3 (1); EWSS at No. 3; FDREC Art 40 (3); EFWRMP Art 5) $[18,19,35,104]$, and on the basis of the Ethiopian Water Resources Management Proclamation, 'water resource management means activities that include water resources development, utilization, conservation, protection and control (EFWRMP Art 2 (19)) [104].'

The inbuilt area of Addis Ababa is found in the Akaki river basin; and the absolute majority of industries in it dispose their effluent into the Akaki River, which joins to the trans-regional Awash River, which crosses the Oromia and Somalia National Regional States of Ethiopia (ESIA WWTPSLER KC at 17) [116].

Concurrently, the Ministry of Water, Irrigation and Electricity of Ethiopia is bound to internalize the cost of restoration of authorized degradation of the Akaki River and to incentivize sustainable effluent management through the practical implementation of a federal effluent charge (Gebregiorgs, M. T. (2016) at 38; EFWRMP Art 20 (1) (c) and 22) [11,104,113,141,142].

In practice, since the federal government has not yet developed the rate of its effluent charge $[113,141,142]$, and there is no effluent charge collection system (Gebregiorgs, M. T. (2018) at 367-370) [127], the MWIEE is neither internalizing the social cost of authorized degradation of the Akaki River nor creating an incentive for the industries to sustainably manage their effluent $[113,141,142]$. 
As a corollary, at the moment, the absolute majority of the industries are barely using the full range of effluent abatement options, and they are directly disposing their untreated effluent into the Akaki River (ESIA WWTPSLER KC at 17) [21,22,25,113,116,141-151].

Thus, it is safe to conclude that, at the moment, the federal effluent charge of Ethiopia is not at all reinforcing the aspiration of Ethiopia to achieve sustainable water resource management by 2030.

\section{Conclusions}

The research assesses the viability of the design of the source, base, scope and rate of solid waste, landfill, sewerage service, and effluent charges in the achievement of sustainable waste management in the AAA of Ethiopia. In this research, the source of environmental tax is subject to the principle of legality as long as it is set up by legislative acts; the scope of an environmental tax in a federal system is appropriate when it is as broad as the scope of the waste being addressed, and is consistent with the fiscal needs of the federal and regional waste management organs. The base of an environmental tax is considered to be efficient when it is targeted to the waste or waste-generating behavior, which helps to incentivize the full range of waste abatement options and can contribute to specification of an optimal tax rate. The rate of environmental tax is considered optimal when it is commensurate with the cost of waste management and it creates an incentive for the realization of sustainable waste management. Correspondingly, this research has first indicated Ethiopia's commitment to a federal system, sustainable waste management, the polluter-pays principle and the distributive and incentive roles of environmental taxes. Secondly, it has shown that waste management is one the goals of sustainable development and it is applicable both in developed and least developed countries. Thirdly, it has displayed the mutual contribution of the achievement of waste management to the progress of sustainable sanitation and water resource management. Fourthly, it has shown the distributive and incentive roles of environmental taxes in the achievement of sustainable waste management. Fifthly, it has indicated that cautious design of the source, base, scope and rate of environmental taxes is a critical determinant for environmental taxes' overall success in addressing the prevalent waste mismanagement in Ethiopia.

This research, having the foregoing benchmark findings in its normative framework, has assessed the viability of the design of the source, base, scope and rate of solid waste, landfill, sewerage service and effluent charges in the practical achievement of sustainable waste management in the AAA. Consequently, it has demonstrated that:

(1) The sources of solid waste, landfill, sewerage service and federal effluent charges are set up by legislative acts, and in turn their sources are subject to the principle of legality, and there is no ground for environmental taxation without representation;

(2) The scope of solid waste, landfill, sewerage service and federal effluent charges is as broad as the scope of the waste being addressed, and it is consistent with the fiscal needs of the federal and the Addis Ababa Administration waste management organs, and in turn their scope is appropriate;

(3) Sludge and effluent are targeted as the bases of the sludge dislodging and federal effluent charges, respectively. Therefore, the sludge dislodging and federal effluent charges' bases efficiently target the wastes, which helps to incentivize the full range of sludge and effluent abatement options and can contribute to specification of their optimal rate;

(4) Water consumption, which is a close proxy of sewage, is targeted as the base of the sewer service charge. Thus, the base of the sewer service charge by and large efficiently targets the sewage-generating behavior, which helps to incentivize the full range of sewage abatement options and can contribute to specification of its optimal rate;

(5) Water consumption is taken as the base of solid waste and landfill charges. Therefore, the base of solid waste and landfill charges does not at all efficiently target the waste or waste-generating behavior and thus does not help to incentivize the full range of solid waste abatement options, nor does it contribute to specification of their optimal rate; 
(6) The rates of solid waste, landfill and sewerage service charges make only a nominal contribution to the cost of solid waste and sewage management, and they barely create an incentive for the residents of the AAA to sustainably manage their solid waste and sewage, and as such their rates are slightly optimal; and

(7) Because Ethiopia has not yet developed the rate of the federal effluent charge, the federal effluent charge neither internalizes the cost of trans-regional water resource degradation nor incentivizes the polluters to sustainably manage their effluent.

As a corollary, the study has concluded that, having a somewhat viable design, solid waste, landfill and sewerage service charges are marginally reinforcing the aspiration of Ethiopia to achieve sustainable sanitation. Correspondingly, the results imply that the aspiration of Ethiopia to achieve sustainable sanitation and water resource management by 2030 is contingent on the cautious design of its waste management taxes.

Funding: This research was funded by The Netherlands Organisation for International Cooperation in Higher Education (Nuffic) grant number NICHE/ETH/020.

Conflicts of Interest: The authors declare no conflict of interest.

\section{References and Notes}

1. 2030 Transforming Our World: The 2030 Agenda for Sustainable Development (2030 Agenda for SD). 2015. Available online: https: / www.un.org (accessed on 30 April 2018).

2. Addis Ababa Action Agenda of the Third International Conference on Financing for Development (AA AA TICFD). 2015. Available online: www.un.org (accessed on 23 May 2018).

3. World Health Organization (WHO). Chemicals and Waste Management: Essential to Achieving the Sustainable Development Goals (SDGs). Available online: http://www.who.int/iomc/publications/IOMC_ CWMandSDG_brochure_final_01Feb18.pdf (accessed on 1 May 2018).

4. Directive 2008/98/EC on waste (Directive 2008/98/EC). Available online: http://ec.europa.eu/ environment/waste/framework/framework_directive.htm (accessed on 27 April 2018).

5. Pigou, A.C. The Economics of Welfare, 1st ed.; Palgrave Macmillan: London, UK, 1932; ISBN 978-0230249318.

6. Murty, M.N. Market-based instruments for pollution abatement in India. In Economics of Environment and Development, 1st ed.; Kumar, P., Ed.; Ane Books: New Delhi, India, 2005; ISBN 10:8180520838.

7. Joseph, S.-A. Environmental taxes-Definitional analysis: Behavioural change or revenue raising. In Environmental Taxation and Green Fiscal Reform Theory and Impact; Kreiser, L., Lee, S., Ueta, K., Milne, J.E., Ashiabor, H., Eds.; Edward Elgar Publishing Limited: Cheltenham, UK, 2014; ISBN 9781783478163.

8. UN 'Agenda 21'. 1992. Available online: https://sustainabledevelopment.un.org/content/documents/ Agenda21.pdf (accessed on 30 April 2018).

9. UN ‘Rio Declaration on Environment and Development'. 1992. Available online: www.un.org/documents/ ga/conf151/aconf15126-1annex1.htm (accessed on 30 April 2018).

10. Snape, J.; de Souza, J. Environmental Taxation Law: Policy, Contexts and Practice; Ashgate Publishing Limited: Aldershot, UK, 2006; ISBN 0754623041.

11. Gebregiorgs, M.T. What are the instrumental roles of the introduction of environmental tax in the realisation of the polluter-pays principle in Ethiopia? SAJELP 2016, 22, 3-43.

12. De Sadeleer, N. Environmental Principles from Political Slogan to Legal Rules; Oxford University Press: New York, NY, USA, 2002; ISBN 978-0-19-928092-6.

13. Definition of Powers and Duties of the Executive Organs of the Federal Democratic Republic of Ethiopia Proclamation (Amendment) (DPDEOFDREA); No. 803/2013, No. 61, 2013.

14. Definition of Powers and Duties of the Executive Organs of the Federal Democratic Republic of Ethiopia Proclamation (DPDEOFDRE); No. 691/2010, No. 1, 2010.

15. Federal Environmental Protection Organs Establishment Proclamation (FEPOEP) of Ethiopia; No. 295/2002, No. 7, 2002.

16. Environmental Protection Authority in Collaboration with the Ministry of Economic Development and Cooperation of Ethiopia. Environmental Policy of Ethiopia (EPE); The Federal Democratic Republic of Ethiopia: Addis Ababa, Ethiopia, 1997. 
17. Environmental Protection Authority in Collaboration with the Ministry of Economic Development and Cooperation of Ethiopia. National Conservation Strategy Volume II (NCS II); The Federal Democratic Republic of Ethiopia: Addis Ababa, Ethiopia, 1996.

18. Ministry of Water Resources. Ethiopian Water Resources Management Policy (EWRMP); The Federal Democratic Republic of Ethiopia: Addis Ababa, Ethiopia, 2001.

19. Ministry of Water Resources. Ethiopian Water Sector Strategy (EWSS); The Federal Democratic Republic of Ethiopia: Addis Ababa, Ethiopia, 2001.

20. Environmental Protection Authority 'National Report of Ethiopia: UN Conference on Sustainable Development' (Rio+20) (UN CSD Rio+20 NRE). 2012. Available online: https:/ / sustainabledevelopment.un. org/content/documents/973ethiopia.pdf (accessed on 30 April 2018).

21. Ministry of Environment, Forest and Climate Change of Ethiopia. Assessment on Industrial Pollution and the Environmental, Economic and Social Impact (MEFCCE AIPEESI); MEFCCE: Addis Ababa, Ethiopia, 2014.

22. Ministry of Industry of Ethiopia. Summary of Review Works on Environmental Management Practices of Selected Industries in Ethiopia (MIE SRWEMPSIE); Ministry of Industry of Ethiopia: Addis Ababa, Ethiopia 2014.

23. Tsegai, B. Industrial Pollution Control and Management in Ethiopia: A Case Study on Almeda Factory and Sheba Leather Industry in Tigrai National Regional State. Ph.D. Thesis, University of Warwick School of Law, Warwick, UK, 2015. Available online: wrap.warwick.ac.uk/67913/1/WRAP_THESIS_Ghebretekle_2015.pdf (accessed on 29 April 2018).

24. Gebregiorgs, M.T. The role of public interest litigation in the protection of the environment of Ethiopia: The law and the practice. In Mekelle University Cultural Landscapes of Ethiopia Conference Proceedings (MU CLECP); Mekelle University: Mekelle, Ethiopia, 2015.

25. Federal First Instance Court of Ethiopia. Action for Professionals' Association for the People (APAP) vs. the Federal Environmental Protection Authority of Ethiopia; Civil File No. 64902; Federal First Instance Court: Addis Ababa, Ethiopia, 28 February 2007.

26. Addis Ababa Cleanliness Administration Agency (AACAA). Addis Ababa Cleanliness Administration Agency Solid Waste Policy (AACAASWP); AACAA: Addis Ababa Ethiopia, 1995.

27. Bjerkli, C.L. Governance on the ground: A study of solid waste management in Addis Ababa, Ethiopia. IJURR 2013, 37. [CrossRef]

28. Addis Ababa Water and Sewerage Authority. Waste Water Treatment and Reuse Sub-Process 2015 Annual Report (AAWSA WWTRSP 2015 AR); AAWSA: Addis Ababa, Ethiopia, 2015.

29. Addis Ababa Water and Sewerage Authority. Waste Water Treatment and Reuse Sub-Process 2016 Annual Report (AAWSA WWTRSP 2016 AR); AAWSA: Addis Ababa, Ethiopia, 2016.

30. Addis Ababa Water and Sewerage Authority. Waste Water Treatment and Reuse Sub-Process 2017 Annual Report (AAWSA WWTRSP 2017 AR); AAWSA: Addis Ababa, Ethiopia, 2017.

31. Addis Ababa City Government 2006 E.C. Fiscal Year Budget Proclamation (AACG 2006 E.C. FY BP); NO. 31/2013, NO. 39, 2013.

32. Addis Ababa City Government 2007 E.C. Fiscal Year Budget Proclamation (AACG 2007 E.C. FY BP); NO. 41/2014, NO. 41, 2014.

33. Addis Ababa City Government 2008 E.C. Fiscal Year Budget Proclamation (AACG 2008 E.C. FY BP); NO. 44/2015 E.C., NO. 44, 2015.

34. Addis Ababa City Government 2009 E.C. Fiscal Year Budget Proclamation (AACG 2009 E.C. FY BP); NO. 47/2016 G.C., NO. 47, 2016.

35. The Constitution of the Federal Democratic Republic of Ethiopia; Proclamation (FDREC); NO. 1/1995, NO. 1, 1995.

36. Addis Ababa City Government Revised Charter Proclamation (AACGRCP); NO. 361/2003, NO. 86, 2003.

37. Report of the World Commission on Environment and Development (RWCED) 'Our Common Future'. 1987. Available online: www.un-documents.net/our-common-future.pdf (accessed on 30 April 2018).

38. Cullet, P. Environment and development-The missing link. In International Economic Law, Globalization and Developing Countries; Faundez, J., Tan, C., Eds.; Edward Elgar: Cheltenham, UK, 2010; ISBN 9781848441132.

39. Verschuuren, J. The growing significance of the principle of sustainable development as a legal norm. In Research Handbook on Fundamental Concepts of Environmental Law; Fisher, D., Ed.; Edward Elgar Publishing Ltd.: Cheltenham, UK, 2016; ISBN 9781784714642. 
40. Verschuuren, J. Sustainable development and the nature of environmental legal principles. PELJ $2006,9$. Available online: https: / ssrn.com/abstract=899537 (accessed on 30 May 2018).

41. Bell, S.; McGillivray, D. Environmental Law, 7th ed.; Oxford University Press: New York, NY, USA, 2008; ISBN 978-0-19-921102-9.

42. Bosselmann, K. The Principles of Sustainability: Transforming Law and Governance; Ashgate Publishing Limited: Hampshire, UK, 2008; ISBN 978-0-7546-7355-2.

43. Ministry of Mines and Energy of Ethiopia. The National Energy Policy of Ethiopia (NEPE); The Federal Democratic Republic of Ethiopia: Addis Ababa, Ethiopia, 1993.

44. Federal Environmental Impact Assessment Proclamation (FEIAP) of Ethiopia; No. 299/2002, No. 11, 2002.

45. Federal Pollution Control Proclamation (FPCP) of Ethiopia; No. 300/2002, No. 12, 2002.

46. Federal Standards for Industrial Pollution Control in Ethiopia (FSIPCE); No. 1/2011, No. 1, 2011.

47. Urban Planning Proclamation (UPP) of Ethiopia; No. 574/2008, No. 29, 2008.

48. Access to Genetic Resources and Community Knowledge, and Community Rights Proclamation (AGRCKCRP) of Ethiopia; No. 482/2006, 2006.

49. Fisheries Development and Utilization Proclamation (FDUP) of Ethiopia; No. 315/2003, No. 32 , 2003.

50. Code of Practice of the Floriculture Sector Council of Ministers Regulation (CPFSCMR) of Ethiopia; No. 207/2011, No. 74, 2011.

51. Public Health Proclamation (PHP) of Ethiopia; No. 200/2000, No. 33, 2000.

52. National Planning Commission of Ethiopia. Growth and Transformation Plan II of Ethiopia Volume I: Main Text (GTPE II) (2015/16-2020/21); The Federal Democratic Republic of Ethiopia: Addis Ababa, Ethiopia, 2016.

53. Finance and Economic Development Bureau of Addis Ababa Administration. Growth and Transformation Plan II (AAA GTP II) (2015/16-2020/21); Addis Ababa Administration: Addis Ababa, Ethiopia, 2016.

54. UN Stockholm Declaration on the Human Environment (UN SDHE). 1972. Available online: www.un-documents. net/aconf48-14r1.pdf (accessed on 30 April 2018).

55. UN ‘Framework Convention on Climate Change' (UN FCCC). 1992. Available online: https://unfccc.int/ resource/docs/convkp/conveng.pdf (accessed on 1 May 2018).

56. UN ‘Convention on Biological Diversity' (UN CBD). 1992. Available online: https://www.cbd.int/doc/ legal/cbd-en.pdf (accessed on 1 May 2018).

57. Ethiopia Biological Diversity Convention Ratification Proclamation (EBDCRP) of Ethiopia; No. 98/1994, No. 88, 1994.

58. AU 'African Convention on the Conservation of Nature and Natural Resources'. 1968. Available online: faolex.fao.org/docs/pdf/mul45449.pdf (accessed on 30 April 2018).

59. Shelton, D.; Kiss, A. Judicial Handbook on Environmental Law; United Nations Environment Programme: Nairobi, Kenya, 2005; ISBN 92-807-2555-6.

60. Gilpin, A. Dictionary of Environmental Law; Edward Elgar Publishing Limited: Cheltenham, UK, 2000; ISBN 1840641886.

61. Markandya, A.; Perelet, R.; Mason, P.; Taylor, T. Dictionary of Environmental Economics; Earthscan Publications Ltd.: London, UK, 2002; ISBN 1-85383-529-3.

62. Alm, J.; Banzhaf, H.S. Designing economic instruments for the environment in a decentralized fiscal system. J. Econ. Survey 2012, 26, 177-202. [CrossRef]

63. Organisation for Economic Co-operation and Development (OECD). Environmentally Related Taxes in OECD Countries: Issues and Strategies; OECD Publications Service: Paris, France, 2001; ISBN 92-64-18731-6. Available online: https://www.cbd.int/financial/fiscalenviron/g-fiscaltaxes-oecd.pdf (accessed on 30 May 2018).

64. Addis Ababa City Government Environmental Pollution Control Regulation (AAEPCR); No. 25/2007, No. 56, 2007.

65. Pitrone, F. Environmental Taxation: A Legal Perspective. Ph.D. Thesis, University of Luiss Guido Carli, Roma, Italy, 2014. Available online: eprints.luiss.it/1291/1/20140217-pitrone.pdf (accessed on 30 May 2018).

66. Wolf, S.; Stanley, N. Environmental Law, 5th ed.; Routledge: New York, NY, USA, 2011; ISBN 10:0-203-84254-5.

67. Kiss, A.; Shelton, D. Guide to International Environmental Law; Martinus Nijhoff: Leiden, The Netherlands, 2007; ISBN 13:978-1-57105-344-2.

68. Ashford, N.A.; Caldart, C.C. Environmental Law, Policy, and Economics: Reclaiming the Environmental Agenda; MIT Press: London, UK, 2008; ISBN 978-0-262-01238-6. 
69. Pearce, D. The Polluter Pays Principle, Briefing Papers on Key Issues in Environmental Economics. Gatekeeper Series No. LEEC 89-03. 2003. Available online: http:/ / www.mekonginfo.org/assets/midocs / 0002714-economy-the-polluter-pays-principle.pdf (accessed on 30 April 2018).

70. The International Bank for Reconstruction and Development (IBRD)/The World Bank (WB) (IBRD/WB). Environmental Fiscal Reform What Should Be Done and How to Achieve It; The International Bank for Reconstruction and Development/The World Bank: Washington, DC, USA, 2005. Available online: http://siteresources. worldbank.org/INTRANETENVIRONMENT/Publications/20712869/EnvFiscalReform.pdf (accessed on 31 May 2018).

71. European Commission. Environmental Taxes: A Statistical Guide; Publications Office of the European Union: Luxembourg, 2013; ISBN 978-92-79-33230-2. Available online: http:/ / ec.europa.eu/ eurostat/documents / 3859598/5936129/KS-GQ-13-005-EN.PDF (accessed on 1 June 2018).

72. Barde, J.-P. Economic Instruments in Environmental Policy: Lessons from the OECD Experience and Their Relevance to Developing Economies; Working Paper No. 92; OECD: Paris, France, 1994.

73. Taddese, L. The Ethiopian tax system: Excesses and gaps. Mich. State Int. Law Rev. 2013, 20. Available online: https:/ / digitalcommons.law.msu.edu/ilr/vol20/iss2/9 (accessed on 30 May 2018).

74. Rodi, M.; Ashiabor, H. Legal authority to enact environmental taxes. In Handbook of Research on Environmental Taxation; Milne, J.E., Andersen, M.S., Eds.; Edward Elgar Publishing Limited: Cheltenham, UK, 2014; ISBN 9781784717599.

75. Vanistendael, F. Legal framework for taxation. In Tax Law Design and Drafting; Thuronyi, V., Ed.; International Monetary Fund: Washington, DC, USA, 1996; Volume 2, Available online: www.imf.org/ external/pubs/nft/1998/tlaw/eng/ (accessed on 13 June 2016).

76. Gomez-Baggethun, E.; Ruiz-Perez, M. Economic valuation and the commodification of ecosystem services. Prog. Phys. Geogr. 2011, 35. Available online: http://ppg.sagepub.com/content/35/5/613.refs.html (accessed on 8 June 2016). [CrossRef]

77. United Nations Environment Programme (UNEP). The Use of Economic Instruments in Environmental Policy: Opportunities and Challenges, 1st ed.; United Nations Publications; UNEP: Nairobi, Kenya, 2004; ISBN 92-807-2391-X. Available online: https://unep.ch/etu/publications/Economic_Instrument_Opp_ Chnall_final.pdf (accessed on 31 May 2018).

78. Bhatia, H.L. Public Finance, 19th ed.; Vikas Publishing House PVT Ltd.: New Delhi, India, 1998.

79. Gaines, S.E.; Westin, R.A. Taxation for Environmental Protection: A Multinational Legal Study; Greenwood Publishing Group: Westport, CT, USA, 1991; ISBN 0-89930-575-X.

80. Fasil, N. Constitution for A Nation of Nations: The Ethiopian Prospect; Red Sea Press: Asmera, Eritrea, 1997; ISBN 1-56902-050-7.

81. Kosonen, K. Regressivity of environmental taxation: Myth or reality? In Handbook of Research on Environmental Taxation; Milne, J.E., Andersen, M.S., Eds.; Edward Elgar Publishing Limited: Cheltenham, UK, 2014; ISBN 9781784717599.

82. Stewart, R.B. Economic incentives for environmental protection: Opportunities and obstacles. In Environmental Law, the Economy, and Sustainable Development; Revesz, R.L., Sands, P., Stewart, R.B., Eds.; Cambridge University Press: Cambridge, UK, 2008; ISBN 0521642701.

83. Kolstad, C.D. Environmental Economics; Oxford University Press: Oxford, UK, 2010; ISBN 9780199732647.

84. Organisation for Economic Co-operation and Development (OECD). Environmental Taxation, a Guide for Policy Makers; OECD Publishing: Paris, France, 2011. Available online: https:/ /www.oecd.org/env/toolsevaluation/48164926.pdf (accessed on 31 May 2018).

85. Commission of the European Communities. Environmental Taxes and Charges in the Single Market; Office for Official Publications of the European Communities: Luxembourg, 1997; ISBN 92-78-15312-5. Available online: aei.pitt.edu/4785/ (accessed on 30 April 2018).

86. WTO/Accession Status: Ethiopia-World Trade Organization. Available online: https://www.wto.org/ english/thewto_e/acc_e/a1_ethiopia_e.htm (accessed on 14 May 2018).

87. The General Agreement on Tariffs and Trade (GATT) Article I. July 1986. Available online: https:/ / www.wto. org/english/docs_e/legal_e/gatt47.pdf (accessed on 20 June 2016).

88. The Federal Government of Ethiopia Financial Administration Proclamation (FGEFAP); No. 648/2009, No. 56, 2009. 
89. A Proclamation to Provide for Financial Administration of Addis Ababa City Government (AAFAP); No. 16/2009, No. 1, 2009.

90. Tesfaye, A. Introduction to Law and the Ethiopian Legal System; Justice and Legal System Research Institute: Addis Ababa, Ethiopia, 2009. Available online: https://chilot.me/wp-content/uploads/2011/06/ introduction-to-law-and-ethiopian-legal-system.pdf (accessed on 30 May 2018).

91. Federal Negarit Gazeta Establishment Proclamation (FNGEP); No. 3/1995, No. 3, 1995.

92. The House of Peoples' Representatives of Ethiopia Rules of Procedures and Members Code of Conduct Regulation (HPRERPMCCR) of Ethiopia; No. 3/2006, No. 3, 2006.

93. Addis Ababa City Government Financial Administration Regulation (AAFAR); No. 39/2011, No. $39,2011$.

94. Federal Courts Proclamation Re-amendment Proclamation (FCPRAP) of Ethiopia; No. 454/2005, No. 42, 2005.

95. Federal Courts Proclamation (FCP) of Ethiopia; No. 25/1996, No. 13, 1996.

96. Federal Supreme Court Cassation Division of Ethiopia. Revenue and Customs Authority of Ethiopia vs. Mr. Daniel Mekonnen; Civil File No. 43781; Federal Supreme Court: Addis Ababa, Ethiopia, 21 July 2010.

97. Civil Code of the Empire of Ethiopia Proclamation (CCEEP); No. 165/1960, No. 2, 1960.

98. Waste Management, Collection and Disposal Regulation of the Addis Ababa City Administration Government Regulation (AAWMCDR); No. 13/2004, No. 29, 2004.

99. Regulation to Determine and Collect the Sanitary Service Tariff of the Addis Ababa City Government (RDCSSTAACG); Regulation No. 25/2009, No. 25, 2009.

100. Addis Ababa Water and Sewerage Authority Re-establishment Proclamation (AAWSARP); No. 10/1995, No. 3, 1995.

101. The Addis Ababa Water Supply and Sewerage Disposal Services Regulations No. 5/1995 (Repealing) Regulations (AAWSSDSRRR); No. 31/2002, No. 1, 2002.

102. Addis Ababa Water Supply and Sewerage Disposal Service Regulations (AAWSSDSRA); No. 31/2003 Amendment Regulation No. 35/2011, No. 35, 2011.

103. Ethiopian Federal Water Resources Management Proclamation (EFWRMP); No. 197/2000, No. 25, 2000.

104. Ethiopian Water Resources Management Regulation (EWRMR); No. 115/2005, No. 27, 2005.

105. Abu, G. An economic analysis of fiscal federalism in Ethiopia. In Proceedings of the International Conference on Development Studies in Ethiopia, Addis Ababa, Ethiopia, 11-12 July 2003. Available online: http:/ /scholarworks. wmich.edu/africancenter_icad_archive/60 (accessed on 13 June 2016).

106. De Mello, L.R., Jr. Fiscal decentralization and intergovernmental fiscal relations: A cross-country analysis. World Dev. 2000, 28. Available online: http://biblioteca.unmsm.edu.pe/redlieds/recursos/archivos/ gestionestado/de\%20mello.pdf (accessed on 30 May 2018). [CrossRef]

107. Oates, W.E. A reconsideration of environmental federalism. In Recent Advances in Environmental Economics; List, J.A., de Zeeuw, A., Eds.; Edward Elgar: Cheltenham, UK, 2002; ISBN 978-1843760023.

108. Federal High Court of Ethiopia. Action for Professionals' Association for the People (APAP) vs. the Federal Environmental Protection Authority of Ethiopia; Civil File No. 62904; Federal High Court: Addis Ababa, Ethiopia, 12 June 2008.

109. The Addis Ababa City Government Executive and Municipal Service Organs Re-establishment Proclamation (AAEMSORP); No. 35/2012, No. 35, 2012.

110. Solid Waste Management Proclamation (SWMP) of Ethiopia; No. 513/2007, No. 13, 2007.

111. Gemal Rashid, Deputy General Manager Sewerage Disposal, Treatment and Reuse Core Process, Addis Ababa Water and Sewerage Authority. Interview by the author in person. Addis Ababa, Ethiopia, 2 April 2014. Transcript is available from the author.

112. Tesfaye Werede, Supervisor of Sewerage System, Addis Ababa Water and Sewerage Authority. Interview by the author in person. Addis Ababa, Ethiopia, 3 April 2014. Transcript is available from the author.

113. Tesfaw Ashagrie, Water Supply and Sanitation Directorate: Environmental Specialist and Team Leader, Ministry of Water, Irrigation and Electricity of Ethiopia. Interview by the author in person. Addis Ababa, Ethiopia, 19 June 2014. Transcript is available from the author.

114. Effluent Tax Focus Group Discussion (Effluent Tax FGD). The FGD was conducted by the author in person. Addis Ababa, Ethiopia, 28 June 2014. Transcript is available from the author. 
115. Zelalem Ketema, Sewer System Monitoring Case Manager, Addis Ababa Water and Sewerage Authority. Interview by the author in person. Addis Ababa, Ethiopia, 4 January 2016. Transcript is available from the author.

116. Addis Ababa Water and Sewerage Authority. Environmental and Social Impact Assessment of Waste Water Treatment Plant and Sewer Line Expansion and Rehabilitation in the Kaliti Catchment (ESIA WWTPSLER KC); Addis Ababa Environmental Protection Authority: Addis Ababa, Ethiopia, 2014.

117. Siebert, H. Economics of the Environment Theory and Policy, 7th ed.; Springer: New York, NY, USA, 2008; ISBN 978-3-540-73706-3.

118. Addis Ababa Cleanliness Administration Agency. Addis Ababa Cleanliness Administration Agency Sanitation Service Delivery Standard (AACAA SSDS); AACAA: Addis Ababa, Ethiopia, 2014.

119. Dawit Ayele, General Manager, Addis Ababa Cleanliness Administration Agency. Interview by the author in person. Addis Ababa, Ethiopia, 1 July 2014. Transcript is available from the author.

120. Tadele Demeko, Deputy General Manager, Addis Ababa Cleanliness Administration Agency. Interview by the author in person. Addis Ababa, Ethiopia, 9 May 2014 and 7 October 2015. Transcript is available from the author.

121. Hamere Kebede, Budget and Plan Process Owner, Addis Ababa Cleanliness Administration Agency. Interview by the author in person. Addis Ababa, Ethiopia, 21 June 2014 and 5 October 2015. Transcript is available from the author.

122. Seifu Nasir, Research, Awareness, Contract and Legal Administrator, Addis Ababa Cleanliness Administration Agency. Interview by the author in person. Addis Ababa, Ethiopia, 8 April 2014 and 5 October 2015. Transcript is available from the author.

123. Solid Waste Tax Focus Group Discussion (Solid Waste Tax FGD). It is conducted by the author in person. Addis Ababa, Ethiopia, 21 June 2014. Transcript is available from the author.

124. Addis Ababa Cleanliness Administration Agency Annual Report of 2015 (AACAA AR 2015); AACAA: Addis Ababa, Ethiopia, 2015.

125. Addis Ababa Cleanliness Administration Agency Annual Report of 2016 (AACAA AR 2016); AACAA: Addis Ababa, Ethiopia, 2016.

126. Addis Ababa Cleanliness Administration Agency Annual Report of 2017 (AACAA AR 2017); AACAA: Addis Ababa, Ethiopia, 2017.

127. Gebregiorgs, M.T. Introducing an administratively feasible environmental tax system in Ethiopia. JELL 2018, $33,327$.

128. Nega Fantahun (General Manager, Addis Ababa Recycling and Disposal Project Office) in Solid Waste Tax Focus Group Discussion (Solid Waste Tax FGD). Solid Waste Tax FGD is conducted by the author in person. Addis Ababa, Ethiopia, 21 June 2014. Transcript is available from the author.

129. Alemayehu Neme, Deputy General Manager, City Administration of Addis Ababa Solid Waste Recycling and Disposal Project Office. Interview by the author in person. Addis Ababa, Ethiopia, 16 April 2014 and 7 October 2015. Transcript is available from the author.

130. Addis Ababa Solid Waste Re-use and Disposal Project Office Annual Report of 2015 (AASWRDPO AR 2015); AASWRDPO: Addis Ababa, Ethiopia, 2015.

131. Addis Ababa Solid Waste Re-use and Disposal Project Office Annual Report of 2016 (AASWRDPO AR 2016); AASWRDPO: Addis Ababa, Ethiopia, 2016.

132. Addis Ababa Solid Waste Re-use and Disposal Project Office Annual Report of 2017 (AASWRDPO AR 2017); AASWRDPO: Addis Ababa, Ethiopia, 2017.

133. Researcher's Video Record-based Observation of Repi Landfill (RVRBO RLF) (Addis Ababa, Ethiopia, 16 April 2014).

134. Nega Getahun, Legal and Insurance Director, Addis Ababa Water and Sewerage Authority. Interview by the author in person. Addis Ababa, Ethiopia, 25 March 2014. Transcript is available from the author.

135. Gemila Mohammed, Waste Water Treatment and Re-use Process Owner, Addis Ababa Water and Sewerage Authority. Interview by the author in person. Addis Ababa, Ethiopia, 4 January 2016. Transcript is available from the author.

136. Nuri Muhammed, Waste Water Treatment Case Manager, Addis Ababa Water and Sewerage Authority. Interview by the author in person. Addis Ababa, Ethiopia, 3 April 2014 and 25 December 2015. Transcript is available from the author. 
137. Tadese Eshete, Kaliti Waste Water Treatment Plant Supervisor, Addis Ababa Water and Sewerage Authority. Interview by the author in person. Addis Ababa, Ethiopia, 28 March 2014. Transcript is available from the author.

138. Solomon Tafese, Addis Ababa Akaki-Kaliti Sub-City Water and Sewerage Manager, Addis Ababa Water and Sewerage Authority. Interview by the author in person. Addis Ababa, Ethiopia, 17 June 2014). Transcript is available from the author.

139. Researcher's Video Record-based Observation of Kaliti Waste Water Treatment Plant (RVRBO Kaliti WWTP) (Addis Ababa, Ethiopia, 28 March 2014).

140. Researcher's Video Record-based Observation of Kotebe Waste Water Treatment Plant (RVRBO Kotebe WWTP) (Addis Ababa, Ethiopia, 25 December 2015).

141. Kifle Alemayehu, Director of Water Utilization, Permit and Administration Directorate, Ministry of Water, Energy and Irrigation of Ethiopia. Interview by the author in person. Addis Ababa, Ethiopia, 3 July 2014. Transcript is available from the author.

142. Zewdu Tefera, Legal Affairs Directorate Director, Ministry of Water, Energy and Irrigation of Ethiopia. Interview by the author in person. Addis Ababa, Ethiopia, 2 April 2014. Transcript is available from the author.

143. Mehari Wendmagegn, Compliance Monitoring and Evaluation Directorate Director, Ministry of Environment, Forest and Climate Change of Ethiopia. Interview by the author in person. Addis Ababa, Ethiopia, 10 April 2014. Transcript is available from the author.

144. Haileslassie Sebhatu, General Manager, Addis Ababa City Government Environmental Protection Authority. Interview by the author in person. Addis Ababa, Ethiopia, 27 March 2014. Transcript is available from the author.

145. Adugna Mekonnen, Deputy Manager, Addis Ababa City Government Environmental Protection Authority. Interview by the author in person. Addis Ababa, Ethiopia, 1 April 2014. Transcript is available from the author.

146. Meseret Mengiste, Environmental Awareness and Pollution Inspection Team Leader, Addis Ababa City Government Environmental Protection Authority. Interview by the author in person. Addis Ababa, Ethiopia, 7 April 2014. Transcript is available from the author.

147. Shimelis Eshetu, Environmental Awareness and Pollution Inspection Officer, Addis Ababa City Government Environmental Protection Authority. Interview by the author in person. Addis Ababa, Ethiopia, 7 April 2014. Transcript is available from the author.

148. Adugna Mengste, Environmental Safeguards Team Leader, Ministry of Industry of Ethiopia. Interview by the author in person. Addis Ababa, Ethiopia, 7 July 2014. Transcript is available from the author.

149. Researcher's Video Record-based Observation of Akaki River (RVRBO AR) (Addis Ababa, Ethiopia, 17 June 2014 ).

150. Federal Supreme Court Cassation Division of Ethiopia. Action for Professionals' Association for the People $(A P A P)$ vs. the Federal Environmental Protection Authority of Ethiopia; Civil File No. 51052; Federal Supreme Court: Addis Ababa, Ethiopia, 3 December 2008.

151. Federal Environmental Protection Authority of Ethiopia (FEPAE). Survey on Environmental Pollution Impact on Akaki and Mojo Rivers; FEPAE: Addis Ababa, Ethiopia, 2006.

(C) 2018 by the author. Licensee MDPI, Basel, Switzerland. This article is an open access article distributed under the terms and conditions of the Creative Commons Attribution (CC BY) license (http://creativecommons.org/licenses/by/4.0/). 